\title{
Social justice-oriented narratives in European urban food strategies: Bringing forward redistribution, recognition and representation
}

\author{
Sara A. L. Smaal ${ }^{1,2} \mathbb{D} \cdot$ Joost Dessein $^{2,3}$ (D) Barend J. Wind ${ }^{4}\left(\mathbb{D} \cdot\right.$ Elke Rogge $^{1}$
}

Accepted: 26 October 2020 / Published online: 7 November 2020

(c) The Author(s) 2020

\begin{abstract}
More and more cities develop urban food strategies (UFSs) to guide their efforts and practices towards more sustainable food systems. An emerging theme shaping these food policy endeavours, especially prominent in North and South America, concerns the enhancement of social justice within food systems. To operationalise this theme in a European urban food governance context we adopt Nancy Fraser's three-dimensional theory of justice: economic redistribution, cultural recognition and political representation. In this paper, we discuss the findings of an exploratory document analysis of the social justiceoriented ambitions, motivations, current practices and policy trajectories articulated in sixteen European UFSs. We reflect on the food-related resource allocations, value patterns and decision rules these cities propose to alter and the target groups they propose to support, empower or include. Overall, we find that UFSs make little explicit reference to social justice and justice-oriented food concepts, such as food security, food justice, food democracy and food sovereignty. Nevertheless, the identified resources, services and target groups indicate that the three dimensions of Fraser are at the heart of many of the measures described. We argue that implicit, fragmentary and unspecified adoption of social justice in European UFSs is problematic, as it may hold back public consciousness, debate and collective action regarding food system inequalities and may be easily disregarded in policy budgeting, implementation and evaluation trajectories. As a path forward, we present our plans for the RE-ADJUSTool that would enable UFS stakeholders to reflect on how their UFS can incorporate social justice and who to involve in this pursuit.
\end{abstract}

Keywords Urban food strategies · Social justice $\cdot$ European cities · Milan Urban Food Policy Pact · Policy analysis

Sara A. L. Smaal

sara.smaal@ilvo.vlaanderen.be

Joost Dessein

joost.dessein@ugent.be

Barend J. Wind

b.j.wind@rug.nl

Elke Rogge

elke.rogge@ilvo.vlaanderen.be

1 Social Sciences Unit, ILVO (Flanders Research Institute for Agriculture, Fisheries and Food), Burgemeester Van Gansberghelaan 115, Bus 2, 9820 Merelbeke, Belgium

2 Department of Agricultural Economics, Faculty of Bioscience Engineering, Ghent University, Coupure Links 653, 9000 Gent, Belgium

3 Centre for Sustainable Development, Faculty of Political and Social Sciences, Ghent University, Poel 16, 9000 Gent, Belgium

4 Department of Spatial Planning and Environment, Faculty of Spatial Sciences, University of Groningen, Landleven 1, 9747 AD Groningen, The Netherlands

\author{
Abbreviations \\ UFS Urban food strategy \\ MUFPP Milan Urban Food Policy Pact \\ SDG Sustainable Development Goal \\ FPC Food policy council
}

\section{Introduction}

Throughout the twentieth century, food security was generally regarded as a rural, agricultural or (supra)national issue. However, in the last three decades academics and practitioners have been increasingly calling for holistic and place-based food policies that promote short food supply chains, healthy and sustainable diets and food waste solutions (Olsson et al. 2016; Pothukuchi and Kaufman 1999; Renting and Wiskerke 2010; Sonnino 2013; Sonnino et al. 2016; Vitiello and Brinkley 2014). Remarkably, urban governments are taking the lead in responding to these calls. This is for example demonstrated in 
The Milan Urban Food Policy Pact (MUFPP), which has been signed by over 200 cities, and various other (inter) national urban food policy networks. Cities create public food procurement plans, provide incentives and disincentives through funding, legislation and regulation frameworks, and establish links and relationships between the different stages and actors of the food chain (Campbell 2004; Day-Farnsworth et al. 2017; Pothukuchi and Kaufman 1999, 2000; Sonnino 2009, 2013). To align their various food governance efforts, cities often develop urban food strategies (UFSs). UFSs are defined here as comprehensive vision documents which outline desirable urban foodscapes for the future, connect and create synergies between different policy domains and objectives and map existing, planned and recommended initiatives, measures and courses of action that are (in)directly linked to food in the city (Candel 2020; Ilieva 2017; Mansfield and Mendes 2013; Sonnino 2016; Wiskerke 2009).

Concurrently with this urban food governance upswing, the notion and contemporary institutional architecture of food security have been scrutinized and challenged by numerous scholars and activists (Candel 2014; Hammelmann and Hayes-Conroy 2015; Holt-Giménez and Shattuck 2011; Lang and Barling 2012; Noll and Murdock 2019; Sonnino 2016; Sonnino et al. 2016; Wald and Hill 2016). This has led to proposals for and adoptions of more comprehensive definitions and frameworks for food security and to the emergence of alternative concepts and movements. Across the world, most prominently in North America, the food justice and food democracy movements are on the rise (Booth and Coveney 2015; Cadieux and Slocum 2015; Glennie and Alkon 2018; Gottlieb and Joshi 2010; Hassanein 2003). Likewise, food sovereignty, rooted in South and Central America, is gaining ground globally through peasant farmer movement La Via Campesina (Alkon and Mares 2012; Anderson et al. 2019; Fairbairn 2012; Schiavoni 2017; Wittman 2011). Meanwhile, academics and practitioners are arguing for and showcasing best practices of urban food policies, programmes and initiatives that are rights-based, and foreground social justice (e.g. Allen 2008, 2010; Bedore 2010; Anderson 2008; Dowler and O'Connor 2012; Hammelman et al. 2020; Tornaghi 2017; Wekerle 2004).

Cities, accommodating an ever growing majority of the world's population, are sites of heightened economic, social and cultural diversity where pressures that shape food insecurity converge and are most visible (Bedore 2010; Sonnino et al. 2019). More importantly, these same urban dynamics and networks allow for creativity, experimentation, knowledge exchange, collective action and social innovation in tackling food system injustices at the city-region level and beyond (Donald and Blay-Palmer 2006; Matacena 2016; Maye 2019; Moragues-Faus and Morgan 2015; Morrow 2019), provided a critical, relational and multi-scalar perspective on urban-rural linkages is nurtured (Sonnino and Coulson 2020).

To explore how European urban governments are taking these dynamics into consideration in their urban food governance efforts, we have examined the social justiceoriented ambitions, motivations, practices and policy trajectories, as these are formulated, agreed on and accounted for in their UFSs. We conducted a qualitative analysis on the UFSs of sixteen European medium-sized cities. We found that justice-oriented food concepts, which are so extensively debated in social movements and academic literature, are actually rarely being deployed by urban governments. In the state-of-the-art and discussion sections, we reflect on reasons for and consequences of this absence. Foremost, we intend to unravel, investigate and classify the various and underexplored ways in which social justice-oriented narratives can be discerned within the European urban food policy domain. In order to identify these narratives we adopt an analytical framework based on the three dimensions of social justice distinguished by Nancy Fraser (2005, 2008b, a) - redistribution, recognition and representation-which will be considered in more detail in the third section of the paper. Essentially, the exploratory document analysis is based on three queries: (1) What social justice-oriented narratives, concepts and frames do cities use in their UFSs?; (2) How do cities propose to alter resource allocations, value patterns and decision rules in their UFSs?; and (3) Who are being/to be supported, empowered and included through current/planned initiatives and policy measures described in the UFSs? In the discussion and conclusion sections we will reflect on the implications of the findings and explore potential directions for future research. This paper lays the foundation for our ambition to develop and test an engagement tool. With this RE-ADJUSTool (REflecting on \& ADvancing Justice in Urban food Strategies Tool), we aim to enable UFS stakeholders in and outside of Europe to unpack, assess and integrate social justice in their specific food policy contexts, both on paper and in practice.

\section{Social justice in urban food policies: state-of-the-art}

Whereas American and Canadian urban food policies have been subject to several extensive cross-case analyses (e.g. Gupta et al. 2018; Hodgson 2012; Ilieva 2017; Neuner et al. 2011; Pothukuchi 2009), academic studies analysing and comparing European food policy documents on a large scale are less prevalent. Presumably because of language barriers, funding restrictions, convenience or desired depth of inquiry, scholars select case studies within the boundaries of one European country (e.g. Calori et al. 2017; Doernberg et al. 2019; Moragues-Faus and Carroll 2018; Sibbing et al. 2019), 
compare a limited number of European case studies with cities outside of Europe (e.g. Baker and de Zeeuw 2015; Coppo et al. 2017; Mansfield and Mendes 2013; Prové et al. 2019; Sonnino 2016) or conduct European cross-country comparisons of at most two cities (e.g. Moragues-Faus and Morgan 2015).

The recent articles of Filippini et al. (2019) (sample of 14 European and 18 non-European cities), Sonnino et al. (2019) (sample of 34 European cities and 9 non-European cities) and Candel (2020) (sample of 19 European cities and 21 non-European cities) form exceptions to this pattern, albeit global in focus, not European. These studies demonstrate how extensive document analyses can provide insights into the scope (range of objectives), degree of targeting (specificity of the policy goals) and substantiality (selection of policy instruments) of UFSs (Candel 2020). Moreover, document analyses of UFSs can demonstrate how urban food governance is interpreted, justified and (planned to be) implemented by policy makers and other stakeholders (Sonnino et al. 2019). Finally, through structured document analyses one can explore commonalities and differences between UFSs in terms of priorities and group them (Filippini et al. 2019). Commonly, they function as exploratory or benchmark studies that help to identify gaps, challenges and directions for future research (Candel 2020).

In our document analysis, we want to explore to what extent social justice is currently a priority in European UFSs and how the theme is described and operationalized. Existing urban food policy analyses seem to provide no satisfying answer to these questions. In some studies, social justice is mentioned as one of the fields or objectives a city may (amongst many other things) focus on (e.g. Baker and de Zeeuw 2015; Candel 2020; Filippini et al. 2019; Hodgson et al. 2012) or as a vital component or pillar within a holistic view on sustainable food governance (e.g. Moragues-Faus and Morgan 2015; Sonnino 2016, 2019; Sonnino et al. 2019; Vieira et al. 2018). However, in these analyses social justice is rarely deconstructed or considered in great detail. In other studies the theme is found to be absent in the policy documents that were analysed (e.g. Doernberg et al. 2019; Sibbing et al. 2019) or social justice is simply not discussed or studied at all.

There are a few urban food policy studies that do provide a more elaborate discussion of social justice. Ilieva (2017) and Olsson (2018), who use the Sustainable Development Goal (SDG) framework for their content analyses, demonstrate how various elements of justice are being tackled through urban food policy actions. This ranges from gender equality (SDG5), reduced inequalities (SDG10) and peace and justice (SDG16), to more implicit, but targeted injustices related to poverty, hunger, health, jobs and land. They do remark that UFS goals are rarely legally binding, are susceptible to shifts in electoral cycles, and require multi-sectoral and cross-scale coordination and inevitable trade-offs between conflicting goals and powers. Another example is Prové et al. (2019) who compare the food policy councils (FPCs) of the cities of Philadelphia (US) and Ghent (Belgium). They focus on the principle of procedural justice, which they define as the equal access of all stakeholders to participate in decision-making and governance processes. The authors take into account that justice-oriented movements and vocabularies have a much less pronounced presence in Europe (as noted by Bickerstaff and Agyeman 2009; Darly and McClintock 2017; Herman et al. 2018; Morgan 2015; Santo and Moragues-Faus 2018), but demonstrate that "even in a context without explicit socio-political attention for justice matters, adopting the notion as an analytical perspective provides important insights into the (dis-)empowering strategies of local actors." (Prové et al. 2019, p. 180) In their analysis, they demonstrate how both FPCs are neither deliberately exclusive nor effectively inclusive, as certain issues receive more attention than others and ambitions do not always include targeted audiences or action steps.

Our document analysis quickly established that the term social justice and justice-oriented food concepts like food justice, food democracy, food sovereignty and food security, are hardly referenced in the sixteen European UFSs we analysed. Given the contested and normative nature of these terms, which are often rooted in situated cultural, geographical and political settings or struggles that transcend the local context of a European city, it is perhaps not surprising that urban policy makers do not publicly advance these labels in formal policy documents. Navin and Dieterle (2018) warn that when privileged and wealthy communities in the Global North decide to participate in a global emancipatory movement such as food sovereignty, with roots in indigenous and peasant struggles in the Global South, this may lead to dilution (i.e. privileged communities embracing a less radical adoption of food sovereignty), false equivalence (i.e. privileged communities falsely comparing disparate food contexts) or even direct opposition (i.e. having conflictual understandings of food sovereignty). Moreover, Horst (2017), who studies the opportunities and constraints of municipal governments in the United States in advancing food justice, mentions that some of her interviewees felt that pushing for radical goals may be too politically risky and may turn off possible allies. She writes that in a corporate food regime and strongly neoliberal policy environment, urban government planners have to deal with a lack of commitment from elected officials, insufficient funding and resources, and competition with other planning objectives. "Planners [...] will have to be pragmatic about where to push for deeper change." (Horst 2017, p. 67). Horst (2017) invites municipal governments to challenge the corporate food regime, by using five points of intervention underlying food justice as a guide for reflexive practice-inequity/trauma, 
land, labour, exchange and democratic process (inspired by Cadieux and Slocum's (2015) 'What does it mean to do food justice?')—and teaming up with grassroots and advocacy organizations.

\section{Analytical framework}

Given the exploratory and European focus of our study, we did not feel comfortable unreflexively adopting either food justice, -sovereignty, -democracy or -security for our analysis, as these concepts are contested and have deep and situated roots in agreements, movements and struggles outside of Europe or that transcend the city level. Instead, we decided to embrace a pluralised and multidimensional notion of justice, similar to Moragues-Faus (2017), Tornaghi (2017) and Coulson and Milbourne (2020), and to focus on the questions, principles, processes and interventions underlying social justice, inspired by Allen (2008), Horst (2017) and Maughan et al. (2020). We argue that Nancy Fraser's three-dimensional theory of justice forms a valuable point of departure for such an analytical framework. According to Fraser $(2005,2008$ b, a), working towards social justice requires social arrangements and the dismantling of institutionalised obstacles to permit all people to participate as peers in social life, or parity of participation. She distinguishes three dimensions when it comes to the 'what' of justice: economic redistribution (equal share), cultural recognition (equal respect) and political representation (equal say) (see Fig. 1).

The dimension 'economic redistribution' considers the allocation of the material resources that people need in order to participate in social life on equal terms. The dimension 'cultural recognition' relates to institutionalised value

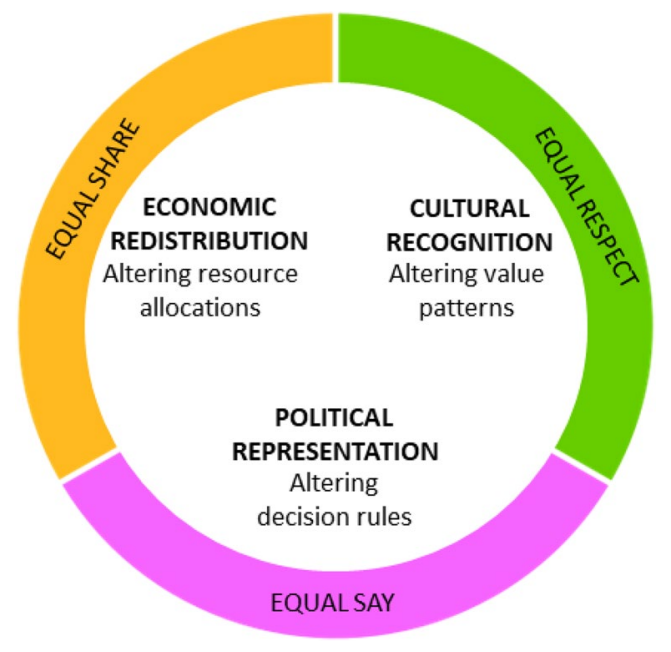

Fig. 1 Visual representation of Fraser's three justice dimensions patterns that can allow or deny people the social status of full partners in social interaction, as well as opportunities for achieving social esteem. The dimension 'political representation' addresses how decision rules around membership and procedures can allow or deny people equal voice in public deliberations and democratic decision-making. In a way, it constitutes the stage on which struggles of redistribution and recognition are played out. We believe that these are three clear, practical and exhaustive principles that urban governments likely are familiar with and will accept, and can be easily translated to a food governance context. Furthermore, this multidimensional approach comprehensively reflects the ongoing theoretical shift from a mere distributional perspective on justice, to one that also includes capability, procedural and participative approaches (see Coulson and Milbourne 2020; Loo 2014; Maughan et al 2020 and Moragues-Faus 2017 for more detailed descriptions of this shift seen within the context of food governance).

In order to further operationalise these three dimensions—reflecting the 'what' of justice—and make the analytical framework operable within an urban food governance context, we also need to address what Fraser (2005, 2008b, $a, 2010)$ terms the 'how' and the 'who' of justice. These layers of the analytical framework have been further developed into categories based on the food-related resources, services, and target groups we came across in our analysis. Accordingly, three questions guide our inquiry:

- What social justice-oriented narratives, concepts and frames do cities use in their UFSs?

- How do cities propose to alter resource allocations (redistribution), value patterns (recognition) and decision rules (representation) in their UFSs?

- Who are being/to be supported (redistribution), empowered (recognition) and included (representation) through current/planned initiatives and policy measures described in the UFSs?

\section{Methods}

\section{Sample}

Similar to the study of Sonnino et al. (2019), the 'MUFPP' and the 'EUROCITIES working group food' networks were taken as point of departure for the case-selection, as membership of these networks is a relatively reliable indicator for recent commitment to food system change (Candel 2020). The MUFPP is a voluntary framework for action for cities aiming to develop sustainable food systems that are inclusive, resilient, safe and diverse, and was launched at the Milan Expo 2015 'Feeding the Planet, Energy for Life'. In July 2019, the commitment was signed by 199 cities from 
all over the world, among which 87 European cities. The EUROCITIES working group food-also formed in 2015aims to set up a European framework to consolidate the path undertaken in the MUFPP and to create a hub for sharing information, ideas, best practices and innovations related to urban food governance. Besides 36 members that have also signed the MUFPP, the working group includes another nineteen non-MUFPP members. Thus, on paper, 106 European cities acknowledge their position and responsibilities within the food system, and want to implement food as a crosscutting theme within their policy frameworks.

However, these cities range from small communes and towns (e.g. Mouans-Sartoux, France and Navàs, Spain) to huge metropoles (e.g. Berlin, Germany and London, UK). Expectedly, the types of problems, priorities and administrative capacity of these government bodies will differ substantially (Candel 2020). Therefore, we decided to focus this research on medium-sized cities with a population size between 100.000 and 500.000 inhabitants. As opposed to other continents, this is quite a typical city size in Europe. 45 of the 105 identified cities fall into this category. However, as pointed out by Sonnino et al. (2019) and Candel (2020), not all MUFPP and EUROCITIES Food cities have also developed UFSs. We performed an extensive web search and sent around email requests to all MUFPP contact persons of cities for which we could not find a UFS. In the end, we were able to identify and obtain UFSs for sixteen cities from six different countries: Basel [CH]; Bristol [UK]; Bruges [BE]; Cordoba [ES]; Donostia-San Sebastián [ES]; Ede [NL]; Geneva [CH]; Ghent [BE]; Grenoble [FR]; Groningen [NL]; Montpellier [FR]; Nantes [FR]; Rennes [FR]; Tours [FR]; Uppsala [SE]; and Vitoria-Gasteiz [ES]. Six of the UFSs are regional or metropolitan collaborations involving urban and rural municipalities.

\section{Exploratory document analysis}

To prepare the policy documents for analysis, text-only files were created for each UFS, which were then translated to English using DeepL Pro software. Any ambiguities in the translated texts were resolved by consulting native speakers within our professional networks. Even so, we acknowledge the possibility that certain meanings and accentuations might have been lost in translation.

These files were uploaded in NVivo 12 for qualitative coding. In the first round of coding, all pieces of texts that contained arguments or practices broadly related to redistribution, recognition or representation, or mentioned justice or social justice-oriented food concepts and movements, were coded within one of the four categories outlined in Table 1.

Subsequently, the four collections of coded material were revisited to be sorted into more detailed sub-nodes. In this stage, there was no pre-set codebook; codes and themes emerged from the data and were reorganised in a reflexive and reiterative process. For example, we decided to convert some of our initial codes-which were mainly reflecting rather general domains (e.g. economy, environment, health, education, etc.), food supply chain stages (from production to waste disposal) and food supply chain types (e.g. fair trade, circular economy, local food networks, public food procurement) and hence difficult if not risky to directly connect to social justice (e.g. in terms of avoiding the local trap, Born and Purcell 2006) — into resources and services categories that the urban governments or described initiatives were in some way providing, facilitating, managing or co-creating in order to achieve more socially just outcomes. These codes provided the basis for describing the 'how' of justice. In order to validate and refine the resources and services codes we triangulated the identified categories with urban food governance literature and positioned the categories around Fraser's three 'what' dimensions. All four authors have actively taken part in this classification process to avoid individual bias. The exercise resulted in seven resources and services categories (food, land, pay, social capital, knowledge, voice and infrastructure), which are further discussed in the results section.

To visualise to what extent each of these resources and services receive attention in the analysed UFSs, we developed a radar diagram (Fig. 2). For all sixteen cities, such a diagram was produced in order to create city summaries and identify patterns. The diagrams represent case-by-case qualitative assessments. We assessed the degree of priority (top, high, moderate, low, absent) given to each of the seven resources and services categories, for each individual UFS. These assessments were based on the relative distribution of
Table 1 Nodes used in the first round of coding

\begin{tabular}{ll}
\hline Node & Description \\
\hline Ambitions & All descriptions of social justice-oriented objectives and plans \\
Motivations & All descriptions of social justice-oriented arguments and drivers \\
Current practices & All descriptions of social justice-oriented initiatives already at play \\
UFS trajectories & All descriptions of social justice-oriented practices incorporated within \\
& the UFS participation and governance trajectories \\
\hline
\end{tabular}




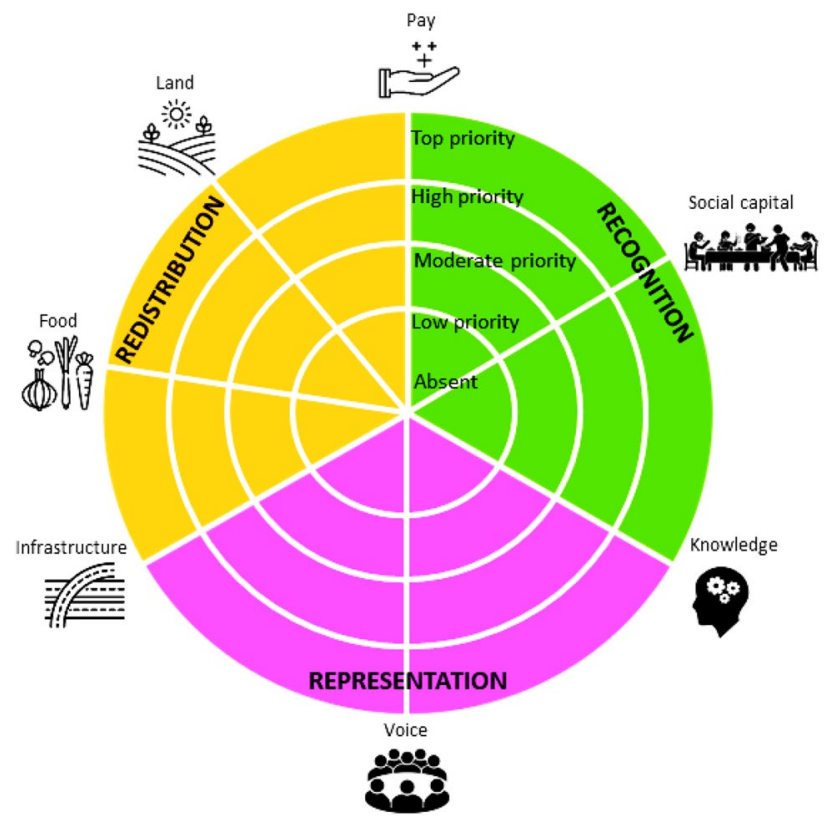

Fig. 2 Radar diagram to assess the priority given to each of the resources and services categories in a UFS

reference counts, and the variety, level of detail and centrality of the coded references, taking into account the length, scope, style, and structure of the concerned UFS. In other words, they rest on informed judgements, not calculations. The process of qualitative coding and assessing is always personal. We think it is important to be transparent about this process, but we acknowledge the possibility that somebody who would replicate our work could come up with different codes and assessments. We also want to stress that the diagrams reflect how the seven categories are being addressed in the UFS policy texts; whether they are also prioritised and implemented in practice or in other policies falls outside the scope of this research. In the results section we share our process of working with the diagram and illustrate the diversity of the UFSs by zooming in on the diagrams of three UFSs.

There was also no pre-set code-book for the 'who' of justice. All target groups we came across-those being/to be supported, empowered and/or included-were coded invivo, i.e. labelled exactly as formulated by the cities. Based on the list of in-vivo codes, we developed a classification structure, distinguishing main categories that indicate on what grounds a target group is defined, and sub-categories that cluster the corresponding in-vivo codes. The outcomes of this exercise can be found in the results section (Fig. 4).

Additional to the coding process, notes and annotations were kept, a list of key- and signatory words indicating a link to social justice was documented, hierarchy charts and word clouds were generated and summaries of the UFS features and observations for each city were made in order to critically analyse and become familiar with the qualitative data at hand.

\section{Results}

\section{What}

Social justice has a rather hidden presence in the analysed UFSs. Of the social justice-oriented food concepts raised in the introduction, only food sovereignty (15 mentions in 4 UFSs) is faintly touched upon. More general social justice-oriented words-e.g. just(ice) itself (only 3 mentions in 2 UFSs), equity/equitable (9 mentions in 5 UFSs), (in)equal(ity/ities) (10 mentions in 6 UFSs) — can each be counted without running out of fingers. Does that mean that European medium-sized cities do not care about creating a more socially just food system? Or do they simply approach the social justice theme with different vocabularies? This subsection highlights the explicit and implicit ways UFSs do seem to include a social justice perspective based on Fraser's three 'what' dimensions (redistribution, recognition and representation) and discusses some issues and obstacles we encountered in the analysis.

What explicit social justice-oriented vocabulary do European cities use? With regard to redistribution, 'access(able/ ibility)' (57 mentions in 11 UFSs), and to a lesser extent 'available/ility' (31 mentions in 13 UFSs) and 'affordable/ ility' (13 mentions in 3 UFSs) are concepts which frequently turn up in the UFSs. Paying the farmer a fair price, shortening food supply chains and buying fair trade products can also be placed within the redistribution dimension of justice as they mean to redistribute income. Arguably, these economic interactions partly relate to recognition as well; for paying a higher price also demonstrates appreciation and challenges existing hierarchy structures and value patterns. Another example of the recognition dimension of justice can be found in the various UFSs that describe food projects which offer marginalised groups, e.g. people with a disability or distance from the labour market, a place to visit, work and/or socialise. Finally, words such as 'participation/ive/ ory'(64 mentions in 13 UFSs) and 'inclusion/inclusive'(14 mentions in 8 UFSs) are featured frequently, illustrating the representation dimension. Moreover, three UFSs are developed by FPCs, in which a wide variety of food system stakeholders are represented, two UFSs are coordinated based on similar types of working groups, and two UFSs include plans to set up an FPC.

Two observations require our attention. First of all, terms such as 'accessible', 'fair' and 'inclusive' are often squeezed into sentences which also include sustainable, healthy, resilient, tasty, prosperous, local, environmentally friendly, organic, etc. A good example of such a sentence is one of 
the main objectives of the MUFPP, which is often repeated in UFSs of cities that have signed the MUFPP: "We will work to develop sustainable food systems that are inclusive, resilient, safe and diverse, that provide healthy and affordable food to all people in a human rights-based framework, that minimise waste and conserve biodiversity while adapting to and mitigating impacts of climate change". Explanations of what 'accessible', 'fair' and 'inclusive' mean and how urban governments plan to operationalise these terms into targets and plans tend to be missing in most UFSs. Secondly, besides the explicit references discussed above, many of the coded social justice-oriented references are of a more implicit nature (e.g. adjectives such as 'responsible', 'collaborative' and 'collective', or verbs like 'supporting', 'promoting' or 'encouraging'). All contain a link to redistribution, recognition or representation, and focus on supporting, empowering or including a group of people to ensure everybody can participate in food practices and food interactions, but the actions are not necessarily framed as being socially just.

With these two observations in mind, the following subsections will dive deeper into the coded material, to see how resource allocations, value patterns and decision rules are being altered and for whom.

\section{How}

As stated in the methodology, we have coded text references to food-related resources and services that the urban government or described initiatives are in some way providing, facilitating, managing or co-creating in order to achieve more socially just outcomes. Below we will demonstrate how the seven categories we identified-food, land, pay, social capital, knowledge, voice and infrastructure - can be positioned alongisde Fraser's three dimensions, how they are present in the analysed UFSs (paragraphs below) and how they are discussed in urban food governance literature (Table 2). Infrastructure, pay and knowledge are all linked to two dimensions. How these three categories are split is indicated in parentheses and illustrated in the examples and questions below.

The categories coded under redistribution demonstrate how urban food systems are driven by complex forces of supply and demand. Material resource allocations frequently discussed in UFSs include:

Infrastructure (physical). An urban food system relies on physical hubs and transportation networks that enable the allocation of food and mobility of people. Not everybody has equal access to this infrastructure. References in this code mainly relate to guaranteeing diversified retail options for urban inhabitants. Urban governments for example establish, promote or protect local markets and artisan businesses where producers and consumers can physically meet one another. Bristol has set out to "strengthen the wholesale, brokerage, and delivery infrastructure that supports the independent food sector logistic". Additionally, various UFSs describe the infrastructural needs in facilitating more sustainable food procurement at hospitals, schools and other public institutions. In total, we coded 104 administrative (see representation) and physical infrastructure references in 14 UFSs.

Food. In the UFSs it is often stressed that healthy, fresh, local, fair, organic and/or sustainable food needs to be accessible for all inhabitants. Accordingly, the supply of these types of food products to or in the city is increased, streamlined and/or promoted. Additionally, the redistribution of food surpluses to people in need and social nonprofit organisations has been a recurring ambition or current practice in the analysed documents, for example in the UFS of Vitoria-Gasteiz: "develop a municipal programme that leads to greater use of food surpluses, in coordination with the major producers of these surpluses (which result from imminent expiry dates or deficiencies in packaging) and with parties in need of these products (food banks, social services, non-governmental organisations, etc.)". Of the seven resources and services categories, food was coded the most (233 references in 16 UFSs).

Land. A vital, but scarce resource needed for food production is land. A number of urban governments in our sample described and intention to play a pro-active role in restoring agricultural land and help small farmers, urban gardeners or food initiatives with land acquisition. Six UFSs discuss ways of connecting landowners and seekers. Others create public gardens where citizens, especially the more vulnerable groups, can come to visit, grow and harvest. Grenoble for example mentioned that they are working on developing "shared and freely accessible plots, gardens and orchards". Finally, there are two cities that experiment with temporary land use conversion for urban agriculture. Land was coded 67 times in 11 UFSs.

Pay (compensation). Only the income that is earned through food-related professions is considered in this code; it does not cover income disparities on the consumer side. References coded in this node for example include shortening food supply chains so the farmer, producer or processor of the food is payed a better price. Additionally, many of the analysed cities are part of fair trade networks, and want to stimulate their citizens and collective caterers to purchase products with a fair trade label to support farmers and production workers in developing countries. Finally, cities mention the creation of employment as an argument for supporting food businesses or programmes, e.g. in Bristol: "If Bristol were to lose this resource it would result in a significant loss of local jobs and in turn cause a domino effect for thousands of producers throughout the South West and 
further afield, and for hundreds of caterers and independent retailers."

The ways we grow, produce, process, eat and value food are also distinctly cultural, which is reflected in the recognition categories. Below we outline three immaterial resources that can play a role in altering institutionalised value patterns in urban food systems:

Pay (appreciation). Besides paying money, food-related labour can also be valued by paying food providers respect and attention. In that regard, redistribution and recognition may reinforce each other and are both needed to challenge existing hierarchy structures and class inequalities (Fraser 2000). In the analysed UFSs, food projects based on volunteers were often mentioned, but there was no particular attention for how such work is or needs to be valued. We did find references that foreground acknowledging and valuing the work of professional food providers: e.g. in Ghent: "In what way exactly, you ask? By showcasing the producer and his work in shops, at the market, in magazines, online, etc. The result? Consumers will show more respect and appreciation for the people producing our food." In total, i.e. in terms of both compensation and appreciation, the resources and services category 'pay' includes 113 references in 15 UFSs.

Social capital. In the UFSs in our sample, it is only modestly highlighted how food brings people together. With 64 references in 13 UFSs, social capital is the least coded category. It covers the distribution of opportunities for people to socialise and practice their cultures and traditions. In various UFSs, urban gardens are presented as multicultural places where different social groups can meet, which increases social cohesion. The city of Geneva also bears in mind cultural diversity: "In multicultural cities, and in the face of increasingly standardized food, eating well must take into account the particularities and diverse food heritages." Finally, social food events are presented as a way to get people, e.g. the elderly, out of isolation.

Knowledge (learning). After food, knowledge is the most frequently referred to category in terms of resources and services to share, circulate and promote (143 references in 16 UFSs). Concerns are raised whether urban inhabitants, especially children, know what is a healthy and sustainable diet and where and how their food is produced. In addition, the competences urban gardeners and local farmers need to operate productively and sustainably and for (home) chefs and collective caterers to serve affordable and healthy meals are considered as skills that can be learned. For example, one of the five pillars in the UFS of Grenoble is called "Inform, raise awareness. The city provides the reader with a list of what they have been doing in terms of cooking workshops, education programmes and knowledge exchange platforms to stimulate knowledge development.

Finally, urban food systems are defined by power relations and decision rules, related to the representation dimension.
We found that three elements are particularly emphasized when it comes to fostering representation and equal say in urban food strategies:

Knowledge (transparency). Urban governments stress that they want their citizens to be able to make informed decisions with regard to food engagement. Many cities facilitate awareness campaigns and events and explain or introduce food-labelling systems in order to make information about the food system more accessible to the public. For example Montpellier: "The Metropolis and its partners have noted that the final consumer is not familiar with the seasonal nature of local products and that there is a need to know where to buy good and/or local products. The idea therefore emerged to offer a reference point to the citizen in his conquest of a more local consumption and to help him to reclaim his food."

Voice. Many of the analysed UFSs are developed in collaboration with other partners, by FPCs and/or based on processes of citizen meetings, surveys and workshops, indicating that the urban governments are providing stakeholders a voice in decision-making. For example, in Donostia-San Sebastián: "It is proposed to establish a committee of experts on the Food Strategy to advise on and support programmes and actions. A participative process will be opened so that the agents, as well as the citizenship can participate." The category 'voice' was coded 83 times in 15 UFSs. Although the vast majority of the references concern the UFS trajectory itself, there were also a couple of references to democratic procedures and project co-ownership in external projects. Also, in some UFSs citizens are invited to vote or provide ideas about what food activities they want in a public space, or even to temporarily take over certain public services from the urban government, like the maintenance of public green. As observed earlier, decision rules stating how words like 'inclusive' or 'participative' have been operationalized often remain undefined, which makes it difficult to assess to what extent citizens can really participate in decision-making on equal terms.

Infrastructure (administrative). This category concerns food-related support platforms and regulatory structures in the urban food system. It includes references to infrastructure that guides, connects or facilitates certain food initiatives and networks, but also examples of regulations being altered to stimulate desired development or behaviour. Many cities also provide funding opportunities for entrepreneurs or citizen initiatives, provided they meet certain qualifications, like in Bruges: "The city of Bruges has organized a competition to support its sustainable food policy. Several projects were financially supported within the framework of "Klimaatneutraal Brugge 2050" (a climate neutral Bruges by 2050)."

We have validated the relevance of these seven categories-or ten if you count the categories we split up-by 
Table 2 How are the resources and services categories being discussed in urban food governance literature?

\section{Redistribution}

Infrastructure (physical)

Food

Land

Pay (compensation)
To what extent can people access transportation and networks in order to distribute, trade or purchase food?

To what extent do people have access to sufficient, safe and nutritious food?

To what extent do people have access to sites to grow, produce or prepare food?

To what extent do people performing food-related labour have access to a decent income?
Discussed in literature on i.a. local food hubs, retail access and supply chain management (e.g. Berti and Mulligan 2016; Bloom and Hinrichs 2011; Horst et al. 2011; Sonnino 2016; Walker et al. 2010)

Discussed in literature on i.a. urban food security, food poverty and food surplus recovery (e.g. Bedore 2010; Dixon et al. 2007; Dowler and O'Connor 2012; Galli et al. 2018; Silver et al. 2017; Weymes and Davies 2019)

Discussed in literature on i.a. urban agriculture, the commons and land use zoning and planning (e.g. Horst et al. 2017; Kerssen and Brent 2017; Manganelli and Moulaert 2019; Morrow 2019; Tornaghi 2014, 2017)

Discussed in literature on i.a. fair trade, short food supply chains and community-supported agriculture (e.g. Dragusanu et al. 2014; Galt 2013; Saulters et al. 2018; Cadieux and Slocum 2015)

Recognition

Pay (appreciation)

To what extent do people performing food-related labour feel acknowledged, valued and respected?

Social capital

To what extent are people able to connect with others through food-related activities?

Discussed in literature on i.a. food sovereignty, food project volunteering and reproductive work (e.g. Akram-Lodhi 2015; Allen and Sachs 2007; Hibbert et al. 2003; Sherriff 2009)

Discussed in literature on i.a. community food sharing, cultural food practices, and trust and reciprocity (e.g. Blake 2019; Brons et al. 2020; Dunbar 2017; Glowacki-dudka et al. 2013; Martin et al. 2004; Trivette 2017)

Knowledge (learning) To what extent are people able to practice, share and learn food-related expertise

Discussed in literature on i.a. local and indigenous food knowledges, food education and capacity building (e.g. Anderson et al. 2019; Blay-Palmer et al. 2016; Kneafsey et al. 2017; Meek and Tarlau 2016; Šūmane et al. 2018)

Representation

Knowledge (transparency)

To what extent do people have access to transparent information about the food systems they participate in?

Discussed in literature on i.a. food democracy, food citizenship, food supply chain transparency (e.g. Anderson 2008; Baldy and Kruse 2019; Booth and Coveney 2015; Hassanein 2003; Trienekens et al. 2012; Wilkins 2005)

Voice

To what extent do people have an equal say in decision-making on food-related issues?

Discussed in literature on i.a. food system power relations, food policy councils and civil society roles (e.g. Bradley and Herrera 2016; Crivits et al. 2016; Horst 2017; Koc et al. 2008; Prové et al. 2019; Schiff 2008)

Infrastructure (administrative) To what extent do people have access to support and protection through network platforms, funding structures and legislation?
Discussed in literature on i.a. alternative food networks, digital platforms and policy instruments (e.g. Buchan and Cloutier 2015; Cerrada-Serra et al. 2018; Ciulli et al. 2019; Manganelli et al. 2019; Sibbing et al. 2019) triangulating them with urban food governance literature. Table 2 summarizes the categories by rephrasing them as questions and features a number of prevalent academic concepts and literature references examining these resources and services. Several of these concepts are not discussed in the
UFSs we have analysed, indicating that there might be some significant gaps between research and practice in Europe in terms of knowledge and priorities.

As explained in the methods section, we have developed a radar diagram to visualise to what extent each of 
the resources and services receives attention in each UFS (Fig. 2). Based on the distribution of priorities, i.e. the shapes of the diagrams, we were able to group cities together. There are those diagrams with one, two or three resources or services not receiving any attention (category A: Basel, Cordoba, Rennes, Tours and Uppsala), those that tick all the boxes fairly evenly, scoring two or three on nearly all resources and services (category B: Bristol, Ghent, Geneva, Grenoble, Groningen and Vitoria-Gasteiz), and those that address all categories, but show a strong tendency towards a couple of resources or services specifically (category C: Bruges, Donostia-San Sebastián, Ede, Montpellier and Nantes). The allocation of cities across these categories appears to be quite random in terms of size and geographical location, i.e. cities from the same country do not all end up in the same group and there are both smaller and larger cities present in each group. It is noticeable that the five cities in category A tend to have relatively concise UFS documents, whereas the cities in categories $\mathrm{B}$ and $\mathrm{C}$ tend to have more comprehensive and longer UFS documents. Also, the UFSs in the category $\mathrm{B}$ tend to be oriented towards a number of abstract objectives, while the UFSs in categories A and C seem to be more project-based and practice-oriented.

In Fig. 3a, b and c, we zoom in on three cities, one from each category, to provide case-specific insights into the coded material behind the diagrams. The UFS of Cordoba is an example of a city in category A, for both land and infrastructure are not touched upon. Also, no descriptions of current practices were identified for this UFS. The focus is mainly on three resources and services: pay (due to its elaborate coverage of the advantages of shortening food supply chains and choosing fair trade in their ambitions and motivations), voice (since the publication is mentioned to be a product of a participatory process) and knowledge (because the UFS emphasizes its function to inform the reader on how to contribute to a more sustainable food system). All in all, it is more of an information booklet than a policy document; the responsibility to act is mainly placed with the citizen, not the municipality itself. The UFS of Ghent clearly fits category $\mathrm{B}$; it is a relatively long document with many multi-layered ambitions and descriptions of projects that are already taking place. Access to food is a central theme in the document; it is approached fairly explicitly and from various angles. For all resources and services categories multiple references were found. Finally, Fig. $3 c$ shows our assessment of the UFS of Donostia-San Sebastián, a city in category C. The spider web shape is skewed towards food, voice and knowledge, and hence mainly covers the representation dimension of Fraser. Notably, this UFS touches upon the social justice theme quite explicitly in the description of current practices and the UFS trajectory, but less so in its future ambitions.

\section{Who}

Healthy meals for whom? Education of whom? A fair price for whom? Decision-making by whom? These questions need to naturally accompany discussions of the 'what' and 'how' of justice. Who is (supposed to be) benefitting from the existing and planned initiatives, programmes and policy measures in the UFSs?

Based on the obtained list of in-vivo target group codes, we designed a classification structure (Fig. 4). We distinguish main categories that indicate on what grounds a target group is defined, and sub-categories that cluster the corresponding in vivo codes. The categories are listed in order of occurrence, based on the total number of coded references. Some target groups fall into multiple categories, e.g. children from low-income households, or rural farmers. The material coded under 'unspecified', are references in which cities make no distinctions as to who to reach out to, e.g. for/ of/with all, everyone, people, inhabitants, citizens, society, you, etc. The material coded under the various 'from all/ no matter/throughout' sub-categories are references that do cover the main category, but do not opt for one specific subcategory. For example: 'from all backgrounds', 'no matter where they live', 'throughout the food supply chain', 'young and old', 'rich and poor', or 'public and private'. The codebook is not "exhaustive"; it only includes those target groups that are mentioned in the analysed UFSs.

As the list indicates, target groups are mainly defined across the food supply chain, organisational structures and generations. Notably, the UFSs do not often distinguish target groups by backgrounds, lifestyles and geographical areas. That is an interesting finding, as these are categories that (especially North American) food justice scholars (e.g. Alkon and Agyeman 2011; Bradley and Herrera 2016; Cadieux and Slocum 2015; Clendenning et al. 2016; Glennie and Alkon 2018; Gottlieb and Joshi 2010; Passidomo 2014; Slocum and Cadieux 2015) tend to emphasize. Possibly, intersectional, racial and class-based inequalities are less present or less publicly discussed in European food governance. Or perhaps European cities tackle such inequalities more implicitly in their UFSs, by articulating policy measures as being directed to or beneficial for 'all'. After all, the main category 'unspecified' includes 151 references in 15 UFSs. If one would also count the 'from all/no matter/throughout' codes, the total of unspecified target groups even adds up to 189 . We also identified numerous references that do not even mention a target group, for instance: "Our focus is on strong social cohesion and more social employment. Education must maximise our efforts in the long term. We also need sound knowledge building on access to food, among other topics, so as to develop well-founded actions." (Ghent). After unspecified, the most mentioned target groups are children (68 mentions in 13 UFSs), farmers and 

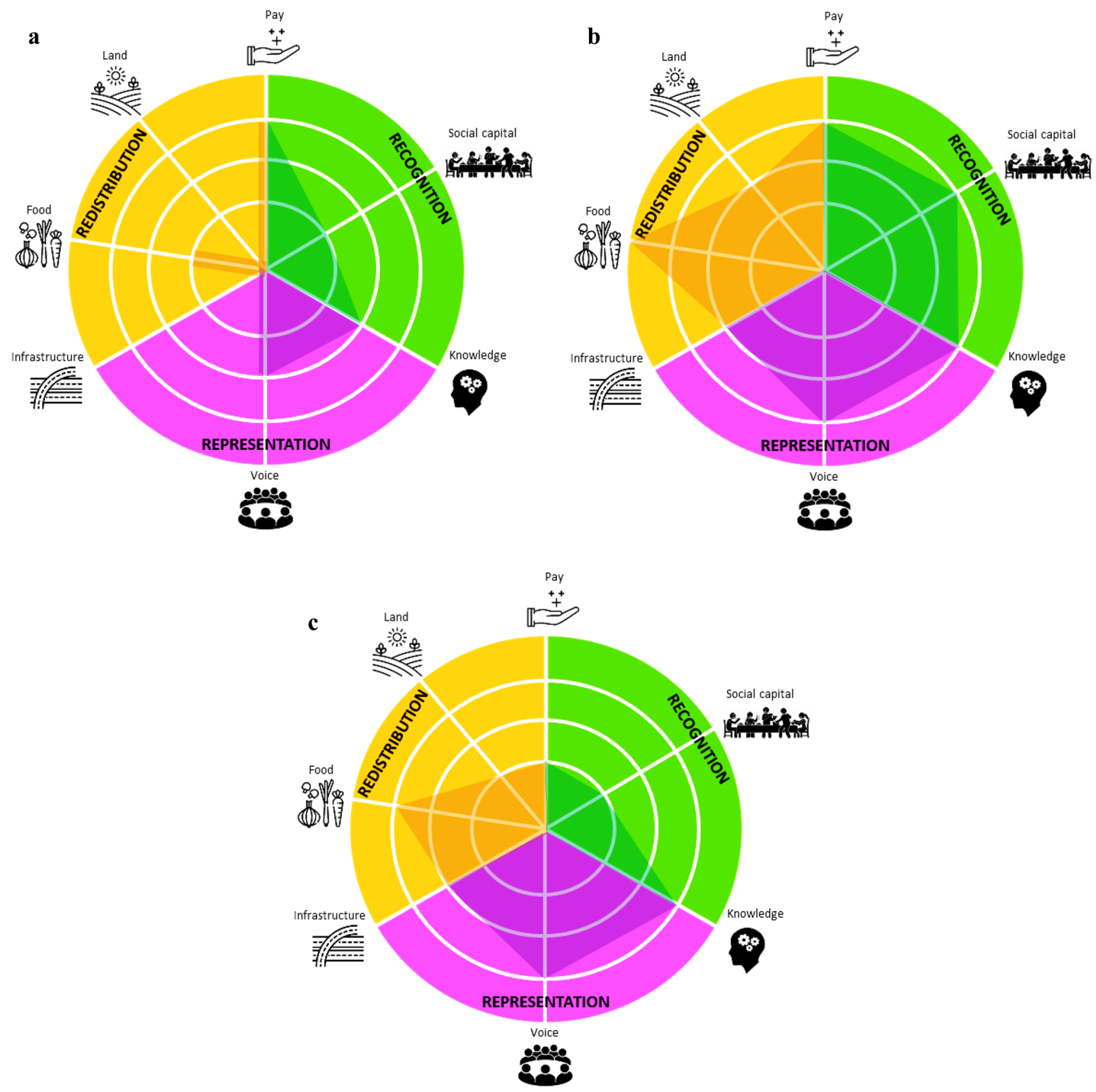

Fig. 3 Resources and services diagrams of Cordoba (a), Ghent (b) and Donostia-San Sebastián (c)

producers (58 mentions in 16 UFSs) and citizen initiatives and start-ups and young entrepreneurs (together 45 mentions in 13 UFSs), reflecting a focus on food education \& school meals, fair food supply chains \& urban-rural linkages, and local social economy \& community cohesion, respectively:

- 'Involve every school in the 'Healthy Schools' approach to food and make food growing and farm visits part of every child's education" (Bristol)
- "Fair trade means that farmers in the South receive a fair price for their product. It also means that the products have been made in people- and environment-friendly conditions." (Bruges)

- "We choose to help pioneers and early adopters by connecting, supporting, facilitating, being involved and guiding them" (Groningen)

Target groups are approached in three distinctive ways: Firstly, those who are supported, i.e. when the target group 


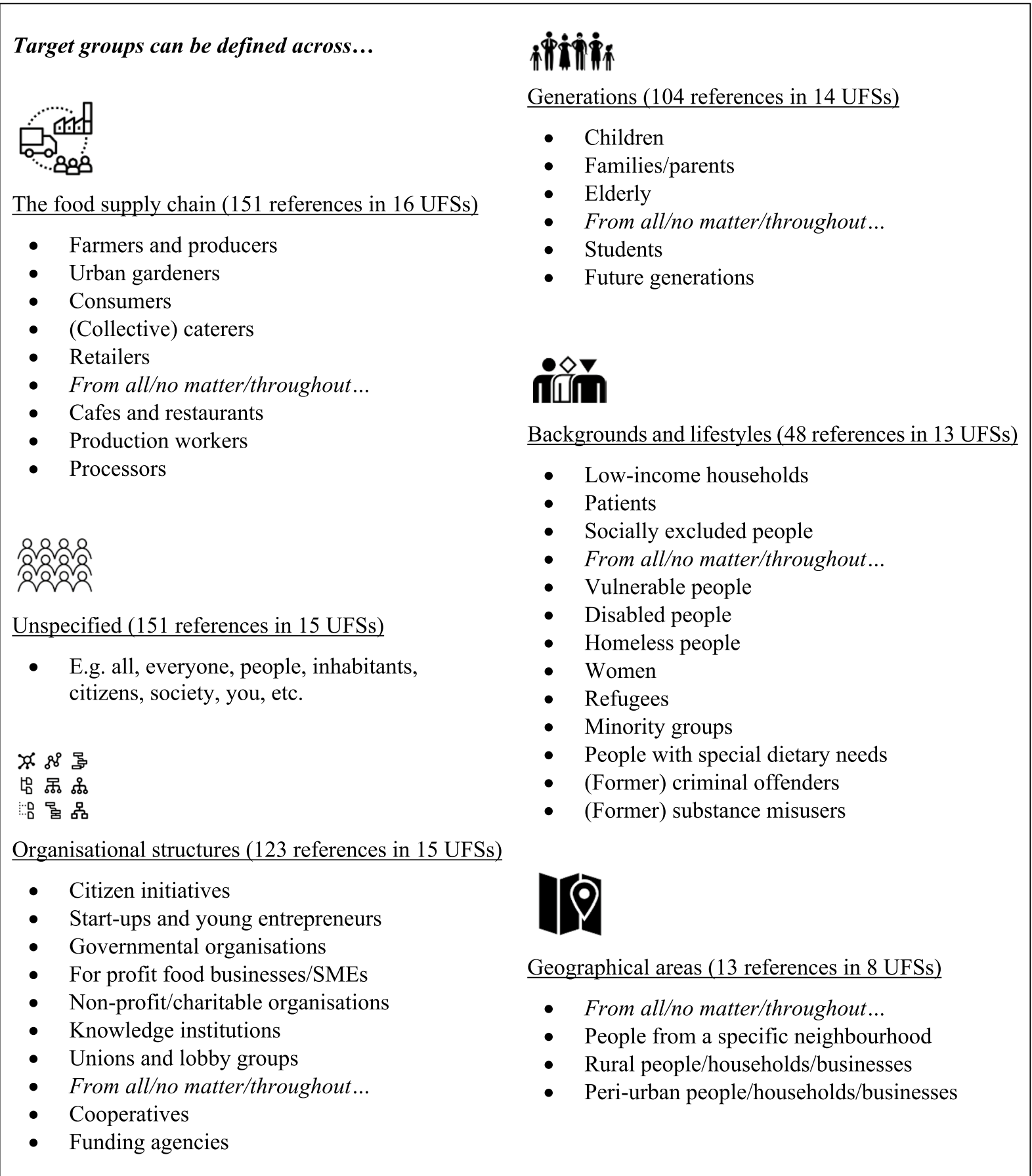

Fig. 4 Classification structure of target groups, in order of occurrence

is provided with resources (focus on redistribution). For example: "Tours Metropole will have a tool that will simplify the acquisition of agricultural land to make it available to farmers." (Tours). Secondly, those who are empowered, i.e. when the target group is provided with opportunities (focus on recognition). For example: "The Severn Project, a Community Interest Company founded in 2010, produces $300 \mathrm{~kg}$ of top-quality organic salad leaves per week to sell commercially, and provides education, training and employment for socially excluded individuals.” (Bristol). 3) And 
thirdly, those who are included, i.e. when the target group is provided a seat at the table (focus on representation). For example: "Following on from the efforts of the federal government, the Canton of Basel-Stadt is launching a Food Waste Round Table with representatives from production, processing, retail trade and social institutions." (Basel).

To give an idea of how individual cities address target groups, we return to the three cities discussed in the previous sub-section. For Cordoba, only sixteen references to target groups were identified, mainly producers and workers in fair trade chains ( 6 references) and those who were involved in some way in the food policy publication (6 references). The former are mainly approached from the lens of recognition and the latter clearly falling in the representation dimension. The remaining four target groups, ranging from shops to non-profit organisations, receive support (redistribution). For Ghent many different target groups were identified, most commonly farmers, urban gardeners, consumers and social initiatives, as well as many references within the unspecified category. All three dimensions are targeted: most target groups were stated to be(come) included in food (policy) practices (representation, 45 references), followed by targets groups that were supported in terms of improved access to resources (redistribution) and empowered in terms of interaction and development opportunities (recognition) (both around 25 references). For Donostia-San Sebastián around fifty target groups were identified. Most target groups (27 references) relate to representation. Both citizens and food sector agents are stated to be(come) included in local alliances to develop, implement and reach food policy objectives. Moreover, various projects are mentioned in which socially excluded groups ( 7 references) are supported (redistribution) and empowered (recognition).

When looking at the other cities in categories A, B and $\mathrm{C}$, the identified target groups are different for each city in terms of characteristics. Patterns can be identified in terms of quantities: category $\mathrm{B}$ and $\mathrm{C}$ cities tend to have more references to target groups than cities in category A. Also, in terms of coverage, category B cities tend to have references to target groups in ambitions, current practices and UFS trajectory descriptions, in all 'what' dimensions and in most target group categories listed in Fig. 4. Whereas in category $\mathrm{A}$ and $\mathrm{C}$ cities target groups tend to be more unevenly dispersed across dimensions and categories.

\section{Discussion}

Social justice has a rather hidden presence in the sixteen analysed European UFSs. First of all, references to social justice-oriented notions are often implicit. We found very few explicit mentions of social justice, food security, food justice, food democracy and food sovereignty. When social justice-oriented words, such as accessible, fair and inclusive, are mentioned, they are not always explained or operationalised. Secondly, the conceptions of social justice-oriented challenges are often fragmentary. For example, some of the analysed UFSs tend to be mainly consumer-focused, ignoring other stakeholders, stages and aspects of the food supply chain. Moreover, certain resources and services that can be facilitated to achieve more socially just outcomes tend to be overlooked, e.g. the discussion about land access or opportunities for people to collectively practice their food cultures. Finally, because many UFSs are vision-oriented they tend to focus on best practices, plans and positive impacts, but omit to acknowledge critical barriers, problems and inequalities in the urban food system. Thirdly, social justice-oriented measures are often unspecified. Many of the policy objectives are formulated to be beneficial for all with little concrete descriptions of policy targets, indicators and instruments. When urban governments are using abstract language and generalizations, such as "serving all citizens" or "healthy food for all", without mentioning specific stakeholders or targeted action steps, they are avoiding complicated but necessary justice-related conflicts and trade-offs (Prové et al. 2019).

We argue that this hidden presence of social justice in European UFSs is rather problematic. When power imbalances, malnutrition and poverty are rarely addressed and acknowledged as urgent and pressing themes within urban food governance, public consciousness around these problems and inequalities in urban food systems is likely to remain low (as discussed in Anderson 2008; Dixon 2014; Kirwan and Maye 2013; Levkoe 2006). Also, when urban governments do not publicly commit to tackling power imbalances, cultural prejudices and social exclusions in their cities' food environments, marginalized communities might not feel heard or empowered to take collective action (as discussed in Crivits et al. 2016; Dowler and O'Connor 2012; Horst et al. 2017; Maughan et al. 2020). Finally, without clear targets, beneficiaries or indicators related to the social values of food, the theme is likely easily disregarded in policy budgeting, implementation and evaluation trajectories (as discussed in Candel 2020; Cleveland et al. 2015; Hebinck and Page 2017; Ilieva 2017).

Despite this implicit, fragmentary and unspecified presence of social justice, we have demonstrated that the notions behind social justice-economic redistribution, cultural recognition and political representation-are at the basis of many of the UFS measures described. How to bring this forward?

Scholars are engaging more and more explicitly with justice frames "from different angles, including rights, democracy, sovereignty, race, class, social reproduction and morality, all of which raise important questions about entitlement, control, ownership and responsibility within a 
food system." (Bedore 2010, p. 1427). In a special issue on new spaces of food justice, Herman and Goodman (2018, p. 1042) argue how we have reached a point where it is not enough anymore to merely talk about food justice, "but rather it needs to be explicitly enacted through everyday and ongoing action that is increasingly international and outside of U.S.-based contexts." However, while citizens and social movements around the world are calling for food justice, food sovereignty and/or food democracy, urban governments rarely seem to be responding to or adopting these bottom-up movements and terminology, and when they do, critical and reflexive descriptions of these concepts are often missing. For example, the marketing and assumptions behind 'buy local' or 'buy fair trade' labels and campaigns are rarely explicated or questioned (Born and Purcell 2006; Getz and Shreck 2006; Goodman 2004; Hinrichs and Allen 2008; West 2010).

A recent paper of Maughan et al. (2020) offers a useful and critical approach to "reading for social justice" in policies, which came out after we had done our analysis, but is in many ways affirmative as well as complementary to our analytical framework. They summarize their approach in a series of five questions:

- Do the policies enable the distribution to (and participation of) the most marginalized?

- Do the polices attempt to build alliances across boundaries?

- Do the policies address spatial and temporal injustices?

- Does the policy process prefigure democratic participation?

- Does the policy process create space for reflexive learning?

We argue that UFS stakeholders-from policy, business, movements and academia — need to be able to contemplate such questions and operationalise social justice amongst each other, by engaging in dialogues about why, how and for whom to pursue a more socially just food system, making the abstract theme more concrete. The research steps followed in this paper, combined with the radar diagram, offer an interesting and practical method to bring about such dialogues and bring forward the justice dimensions and queries of Fraser $(2005,2008 \mathrm{~b}$, a). At the moment of writing, we are transforming the framework into an engagement tool: the RE-ADJUSTool (REflecting on \& ADvancing Justice in Urban food Strategies Tool). Stakeholders of already launched UFSs could use the tool to evaluate how the three dimensions are currently incorporated in their cities' UFS documents and how to further advance social justice in the implementation stage. Urban governments that still have to develop a UFS could employ the RE-ADJUSTool to formulate and operationalize social justice-oriented UFS objectives and measures, ideally in consultation and collaboration with the intended target groups. Finally, if revisited on a regular basis, the RE-ADJUSTool could also be employed to monitor progress and needs, for urban food practices, networks and contexts are subject to continuous change. We are collecting feedback on the tool through workshops in two in-depth case studies and at academic and practitioner events. The RE-ADJUSTool will be publicly launched and disseminated at the end of the research project (Summer 2021).

\section{Conclusion}

In this paper, we have explored to what extent European medium-sized cities refer to social justice-oriented issues in their UFSs, what resources and services they propose to facilitate and who they intend to support, empower and include in these initiatives and policy measures. We learned that social justice occupies a fairly secluded position. Nonetheless, the identified resources, services and target groups indicate that the notions behind social justice as defined by Fraser (2005, 2008b, a)—redistribution, recognition and representation (the 'what') — are underlying motives throughout the UFSs. With regards to resources and services (the 'how'), the analysed European UFSs tend to mostly focus on making various types of food (local, organic, fair trade, healthy, etc.) more accessible to urban citizens and on developing and sharing food-related knowledge and skills through awareness campaigns, education projects and workshops. Facilitating access to social capital and land tends to be overlooked. In terms of the 'who', it is striking how European UFSs seem to mainly define their target groups based on their role in the food supply chain, organisation type or age, whereas the living areas, backgrounds and lifestyles of communities and individuals are rarely touched upon. European cities seem to shy away from (similar finding in the context of the United Kingdom by Coulson and Milbourne 2020) drawing attention to issues of intersectionality within urban food systems (Smith 2019), and rather present policy measures as being designed and accessible 'for all', making sure not to step on anyone's toes.

We expressed our concern that this implicit, fragmentary and unspecified coverage of social justice in European UFSs might hold back public consciousness, debate and collective action regarding food system inequalities and may be easily disregarded in policy budgeting, implementation and evaluation trajectories. Of course, on their own, cities can only do so much. Achieving socially just food systems requires international, cross-scale and multi-sectoral coordination and radical political and economic regime changes (e.g. Horst 2017; Ilieva 2017; Holt Giménez and Shattuck 2011). Still, we believe that cities are in quite a unique position to promote and advance social justice, because they can reach out to, collaborate with and influence quite a wide range of actors and institutional bodies. Internally, they can tap from 
and invest in the knowledge hubs, alternative food practices and social innovation initiatives their city accommodates. Externally, they can raise the issue with, urge action from and inspire other institutional bodies through (inter)national networks and agreements, like the MUFPP or international research projects.

In order to raise awareness, empower citizens and deliver socially just outcomes, we urge cities to explicitly acknowledge (as advocated in Allen 2008; Bedore 2010; Prové et al. 2019), comprehensively address (as advocated in Meerow et al. 2019; Moragues-Faus 2017; Tornaghi 2017) and concretely target (as advocated in Blake 2019; Candel 2020; Crivits et al. 2016) social justice issues in their urban food policies. Based on the research steps followed in this paper, we have put forward our ideas and plans for the READJUSTool, enabling urban food governance stakeholders to qualitatively assess, reflect on and operationalise how their UFSs or food organisations can incorporate the social justice theme and who to involve in this pursuit. This tool is currently being developed and tested in different cities and contexts.

Of course, the study outlined in this paper was only based on UFS policy texts, and does not cover whether and how the urban governments have "proceeded beyond paper realities" (Candel 2020). Further research is needed on how social justice-oriented urban food policy ambitions are implemented in practice, which departments and stakeholders are involved in this trajectory and how to capture the social impact of this implementation (e.g. Coppo et al. 2017; Freudenberg et al. 2018; Ilieva 2017; Mendes 2008). Because we have seen that UFSs are seldom legally-binding, that the responsibility to act is often placed with the citizen and many food-related resources and services are facilitated by civil society organisations, we also encourage research on accountability in urban food governance (e.g. Hebinck and Page 2017; Slocum and Cadieux 2015; Swinburn et al. 2015). Finally, it would be interesting to explore the links between and integration of social and environmental goals in fostering justice in urban food governance (e.g. Cohen and Reynolds 2015; Coulson and Milbourne 2020; Tornaghi 2017; Purifoy 2014; Prost 2019; Walsh-Dilley et al. 2016). For anyone willing to contribute to this growing body of research, we hope this paper may function as a gentle reminder to continuously consider the 'what', 'how' and 'who' of justice, and perhaps most importantly the 'why'.

Acknowledgements This project has received funding from the European Union's Horizon 2020 research and innovation programme under the Marie Skłodowska-Curie Grant Agreement No 765389. A previous version of this paper was presented at the European Society for Rural Sociology (ESRS) conference in Trondheim (Norway) in 2019. The authors would like to thank the anonymous reviewers for providing thorough, insightful and constructive comments on earlier drafts.
Open Access This article is licensed under a Creative Commons Attribution 4.0 International License, which permits use, sharing, adaptation, distribution and reproduction in any medium or format, as long as you give appropriate credit to the original author(s) and the source, provide a link to the Creative Commons licence, and indicate if changes were made. The images or other third party material in this article are included in the article's Creative Commons licence, unless indicated otherwise in a credit line to the material. If material is not included in the article's Creative Commons licence and your intended use is not permitted by statutory regulation or exceeds the permitted use, you will need to obtain permission directly from the copyright holder. To view a copy of this licence, visit http://creativecommons.org/licenses/by/4.0/.

\section{References}

Akram-Lodhi, A.H. 2015. Accelerating towards food sovereignty. Third World Quarterly 36 (3): 563-583. https://doi.org/10.1080/01436 597.2015.1002989.

Alkon, A.H., and J. Agyeman. 2011. Cultivating food justice: Race, class, and sustainability. Cambridge: MIT Press.

Alkon, A.H., and T.M. Mares. 2012. Food sovereignty in US food movements: Radical visions and neoliberal constraints. Agriculture and Human Values 29 (3): 347-359. https://doi.org/10.1007/ s10460-012-9356-z.

Allen, P. 2008. Mining for justice in the food system: Perceptions, practices, and possibilities. Agriculture and Human Values 25 (2): 157-161. https://doi.org/10.1007/s10460-008-9120-6.

Allen, P. 2010. Realizing justice in local food systems. Cambridge Journal of Regions, Economy and Society 3 (2): 295-308. https ://doi.org/10.1093/cjres/rsq015.

Allen, P., and C. Sachs. 2007. Women and food chains: The gendered politics of food. International Journal of Sociology of Food and Agriculture 15 (1): 1-23. https://doi.org/10.1177/1094428100 34002.

Anderson, C.R., C. Maughan, and M.P. Pimbert. 2019. Transformative agroecology learning in Europe: Building consciousness, skills and collective capacity for food sovereignty. Agriculture and Human Values 36 (3): 531-547. https://doi.org/10.1007/ s10460-018-9894-0

Anderson, M.D. 2008. Rights-based food systems and the goals of food systems reform. Agriculture and Human Values 25 (4): 593-608. https://doi.org/10.1007/s10460-008-9151-z.

Baker, L., and H. De Zeeuw. 2015. Urban food policies and programmes: an overview. In Cities and agriculture: Developing resilient urban food systems, ed. H. De Zeeuw and P. Drechsel, 26-55. London: Routledge.

Baldy, J., and S. Kruse. 2019. Food democracy from the top down? State-driven participation processes for local food system transformations towards sustainability. Politics and Governance 7 (4): 68-80. https://doi.org/10.17645/pag.v7i4.2089.

Bedore, M. 2010. Just urban food systems: A new direction for food access and urban social justice. Geography Compass 4 (9): 1418-1432. https://doi.org/10.1111/j.1749-8198.2010.00383.x.

Berti, G., and C. Mulligan. 2016. Competitiveness of small farms and innovative food supply chains: The role of food hubs in creating sustainable regional and local food systems. Sustainability 8 (7): 616. https://doi.org/10.3390/su8070616.

Bickerstaff, K., and J. Agyeman. 2009. Assembling justice spaces: The scalar politics of environmental justice in North-east England. Antipode 41 (4): 781-806. https://doi.org/10.111 1/j.1467-8330.2009.00697.x. 
Blake, M.K. 2019. More than just food: Food insecurity and resilient place making through community self-organising. Sustainability 11 (10): 2942. https://doi.org/10.3390/su11102942.

Blay-Palmer, A., R. Sonnino, and J. Custot. 2016. A food politics of the possible? Growing sustainable food systems through networks of knowledge. Agriculture and Human Values 33 (1): 27-43. https ://doi.org/10.1007/s10460-015-9592-0.

Bloom, J.D., and C.C. Hinrichs. 2011. Moving local food through conventional food system infrastructure: Value chain framework comparisons and insights. Renewable Agriculture and Food Systems 26 (1): 13-23. https://doi.org/10.1017/S1742 170510000384.

Booth, S., and J. Coveney. 2015. Food democracy: From consumer to food citizen. Singapore: Springer.

Born, B., and M. Purcell. 2006. Avoiding the local trap: Scale and food systems in planning research. Journal of Planning Education and Research 26 (2): 195-207. https://doi. org/10.1177/0739456X06291389.

Bradley, K., and H. Herrera. 2016. Decolonizing food justice: Naming, resisting, and researching colonizing forces in the movement. Antipode 48 (1): 97-114. https://doi.org/10.1111/ anti.12165.

Brons, A., S. Wertheim-heck, and P. Oosterveer. 2020. Feeding the melting pot: Inclusive strategies for the multi-ethnic city. Agriculture and Human Values. https://doi.org/10.1007/s1046 0-020-10031-x

Buchan, R., and D. Cloutier. 2015. Local food system planning: The problem, conceptual issues, and policy tools for local government planners. Canadian Journal of Urban Research 24 (1): $1-23$.

Cadieux, K.V., and R. Slocum. 2015. What does it mean to do food justice? Journal of Political Ecology 22 (1): 1-26. https://doi. org/10.2458/v22i1.21076.

Calori, A., E. Dansero, G. Pettenati, and A. Toldo. 2017. Urban food planning in Italian cities: A comparative analysis of the cases of Milan and Turin. Agroecology and Sustainable Food Systems 41 (8): 1026-1046. https://doi.org/10.1080/21683565.2017.13409 18.

Campbell, M.C. 2004. Building a common table: The role for planning in community food systems. Journal of Planning Education and Research 23 (4): 341-355. https://doi.org/10.1177/0739456X04 264916.

Campbell, M.C. 2016. Building a Common Table. Journal of Planning Education and Research 23 (4): 341-355.

Candel, J.J.L. 2014. Food security governance: A systematic literature review. Food Security 6: 585-601. https://doi.org/10.1007/s1257 1-014-0364-2.

Candel, J.J.L. 2020. What's on the menu? A global assessment of MUFPP signatory cities' food strategies. Agroecology and Sustainable Food Systems 44 (7): 919-946. https://doi. org/10.1080/21683565.2019.1648357.

Cerrada-Serra, P., A. Moragues-Faus, T.A. Zwart, B. Adlerova, D. Ortiz-Miranda, and T. Avermaete. 2018. Exploring the contribution of alternative food networks to food security. A comparative analysis. Food Security 10: 1371-1388. https://doi.org/10.1007/ s12571-018-0860-x.

Ciulli, F., A. Kolk, and S. Boe-Lillegraven. 2019. Circularity brokers: Digital platform organizations and waste recovery in food supply chains. Journal of Business Ethics. https://doi.org/10.1007/ s10551-019-04160-5.

Clendenning, J., W.H. Dressler, and C. Richards. 2016. Food justice or food sovereignty? Understanding the rise of urban food movements in the USA. Agriculture and Human Values 33: 165-177. https://doi.org/10.1007/s10460-015-9625-8.

Cleveland, D.A., A. Carruth, and D.N. Mazaroli. 2015. Operationalizing local food: Goals, actions, and indicators for alternative food systems. Agriculture and Human Values 32 (2): 281-297. https://doi.org/10.1007/s10460-014-9556-9.

Cohen, N., and K. Reynolds. 2015. Resource needs for a socially just and sustainable urban agriculture system: Lessons from New York City. Renewable Agriculture and Food Systems 30 (1): 103-114. https://doi.org/10.1017/S1742170514000210.

Coppo, G., S. Stempfle, and M. Reho. 2017. Urban food strategies and plans: Considerations on the assessment construction. City, Territory and Architecture 4:8. https://doi.org/10.1186/s4041 0-017-0064-2.

Coulson, H., and P. Milbourne. 2020. Food justice for all? Searching for the ' justice multiple' in UK food movements. Agriculture and Human Values. https://doi.org/10.1007/s10460-020-10142 -5 .

Crivits, M., C. Prové, T. Block, and J. Dessein. 2016. Four perspectives of sustainability applied to the local food strategy of Ghent (Belgium): Need for a cycle of democratic participation? Sustainability 8 (1): 55. https://doi.org/10.3390/su8010055.

Darly, S., and N. McClintock. 2017. Introduction to urban agriculture in the Neoliberal city: Critical European perspectives. Acme 16 (2): 224-231.

Day-Farnsworth, L., M. Krome, C. McKinney, and M.C. Campbell. 2017. Community and regional food systems policy and planning. In Good food, strong communities: Promoting social justice through local and regional food systems, ed. S. Ventura and M. Bailkey, 201-227. Iowa: University of Iowa Press.

Dixon, B.A. 2014. Learning to see food justice. Agriculture and Human Values 31 (2): 175-184. https://doi.org/10.1007/s1046 0-013-9465-3.

Dixon, J., A.M. Omwega, S. Friel, C. Burns, K. Donati, and R. Carlisle. 2007. The health equity dimensions of urban food systems. Journal of Urban Health 84 (SUPPL. 1): 118-129. https://doi. org/10.1007/s11524-007-9176-4.

Doernberg, A., P. Horn, I. Zasada, and A. Piorr. 2019. Urban food policies in German city regions: An overview of key players and policy instruments. Food Policy 89: 101782. https://doi. org/10.1016/j.foodpol.2019.101782.

Donald, B., and A. Blay-Palmer. 2006. The urban creative-food economy: Producing food for the urban elite or social inclusion opportunity? Environment and Planning A 38 (10): 1901-1920. https://doi.org/10.1068/a37262.

Dowler, E.A., and D. O'Connor. 2012. Rights-based approaches to addressing food poverty and food insecurity in Ireland and UK. Social Science and Medicine 74 (1): 44-51. https://doi. org/10.1016/j.socscimed.2011.08.036.

Dragusanu, R., D. Giovannucci, and N. Nunn. 2014. The economics of fair trade. Journal of Economic Perspectives 28 (3): 217-236. https://doi.org/10.1257/jep.28.3.217.

Dunbar, R.I.M. 2017. Breaking bread: The functions of social eating. Adaptive Human Behavior and Physiology 3 (3): 198-211. https ://doi.org/10.1007/s40750-017-0061-4.

Fairbairn, M. 2012. Framing transformation: The counter-hegemonic potential of food sovereignty in the US context. Agriculture and Human Values 29 (2): 217-230. https://doi.org/10.1007/s1046 0-011-9334-x.

Filippini, R., C. Mazzocchi, and S. Corsi. 2019. The contribution of Urban Food Policies toward food security in developing and developed countries: A network analysis approach. Sustainable Cities and Society 47: 101506. https://doi.org/10.1016/j. scs.2019.101506.

Fraser, N. 2000. Rethinking recognition. New Left Review 3: 107-118. Fraser, N. 2005. Reframing justice in a globalizing world. New Left Review 36: 69-88.

Fraser, N. 2008a. Abnormal justice. Critical Inquiry 34 (3): 393-422. https://doi.org/10.1086/589478. 
Fraser, N. 2008b. Scales of justice: Reimagining political space in a globalizing world. Columbia: Columbia University Press.

Fraser, N. 2010. Who counts? Dilemmas of justice in a postwestphalian world. Antipode 41: 281-297. https://doi.org/10.111 1/j.1467-8330.2009.00726.x.

Freudenberg, N., C. Willingham, and N. Cohen. 2018. The role of metrics in food policy: Lessons from a decade of experience in New York City. Journal of Agriculture, Food Systems, and Community Development 8 (2): 191-209. https://doi.org/10.5304/jafsc d.2018.08B.009.

Galli, F., A. Hebinck, and B. Carroll. 2018. Addressing food poverty in systems: Governance of food assistance in three European countries. Food Security 10: 1353-1370. https://doi.org/10.1007/ s12571-018-0850-z.

Galt, R.E. 2013. The moral economy is a double-edged sword: Explaining farmers' earnings and self-exploitation in community-supported agriculture. Economic Geography 89 (4): 341-365. https ://doi.org/10.1111/ecge.12015.

Getz, C., and A. Shreck. 2006. What organic and fair trade labels do not tell us: Towards a place-based understanding of certification. International Journal of Consumer Studies 30 (5): 490-501. https://doi.org/10.1111/j.1470-6431.2006.00533.x.

Glennie, C., and A.H. Alkon. 2018. Food justice: Cultivating the field. Environmental Research Letters 13 (7): 073003. https://doi. org/10.1088/1748-9326/aac4b2.

Glowacki-dudka, M., J. Murray, and K.P. Isaacs. 2013. Examining social capital within a local food system. Community Development Journal 48 (1): 75-88. https://doi.org/10.1093/cdj/bss007.

Goodman, M.K. 2004. Reading fair trade: Political ecological imaginary and the moral economy of fair trade foods. Political Geography 23 (7): 891-915. https://doi.org/10.1016/j.polge o.2004.05.013.

Gottlieb, R., and A. Joshi. 2010. Food justice. Cambridge: MIT Press.

Gupta, C., D. Campbell, K. Munden-Dixon, J. Sowerwine, S. Capps, G.W. Feenstra, and J. Van Soelen. 2018. Food policy councils and local governments: Creating effective collaboration for food systems change. Journal of Agriculture, Food Systems, and Community Development. https://doi.org/10.5304/jafsc d.2018.08B.006.

Hammelman, C., and A. Hayes-Conroy. 2015. Understanding cultural acceptability for urban food policy. Journal of Planning Literature 30 (1): 37-48. https://doi.org/10.1177/0885412214555433.

Hammelman, C., C.Z. Levkoe, J. Agyeman, S. Kharod, A. Moragues Faus, E. Munoz, J. Oliva, and A. Wilson. 2020. Integrated food systems governance: Scaling equitable and transformative food initiatives through scholar-activist engagement. Journal of Agriculture, Food Systems, and Community Development 9 (2): 71-86. https://doi.org/10.5304/jafscd.2020.092.003.

Hassanein, N. 2003. Practicing food democracy: A pragmatic politics of transformation. Journal of Rural Studies 19: 77-86. https:// doi.org/10.1016/S0743-0167(02)00041-4.

Hebinck, A., and D. Page. 2017. Processes of participation in the development of urban food strategies: A comparative assessment of Exeter and Eindhoven. Sustainability 9: 931. https:// doi.org/10.3390/su9060931.

Herman, A., M.K. Goodman, and C. Sage. 2018. Six questions for food justice. Local Environment 23 (11): 1075-1089. https:// doi.org/10.1080/13549839.2018.1532401.

Herman, A., and M. Goodman. 2018. New spaces of food justice. Local Environment 23 (11): 1041-1046. https://doi. org/10.1080/13549839.2018.1527302.

Hibbert, S., M. Piacentini, and H. Al Dajani. 2003. Understanding volunteer motivation for participation in a community-based food cooperative. International Journal of Nonprofit and Voluntary Sector Marketing 8 (1): 30-42. https://doi.org/10.1002/ nvsm.199.
Hinrichs, C.C., and P. Allen. 2008. Selective patronage and social justice: Local food consumer campaigns in historical context. Journal of Agricultural and Environmental Ethics 21 (4): 329 352. https://doi.org/10.1007/s10806-008-9089-6.

Hodgson, K. 2012. Planning for food access and community-based food systems: A national scan and evaluation of local comprehensive and sustainability plans. American Planning Association.

Holt-Giménez, E., and A. Shattuck. 2011. Food crises, food regimes and food movements: Rumblings of reform or tides of transformation? Journal of Peasant Studies 38 (1): 109-144. https://doi. org/10.1080/03066150.2010.538578.

Horst, M. 2017. Food justice and municipal government in the USA. Planning Theory and Practice 18 (1): 51-70. https://doi. org/10.1080/14649357.2016.1270351.

Horst, M., N. Mcclintock, and L. Hoey. 2017. The intersection of planning, urban agriculture, and food justice: A review of the literature. Journal of the American Planning Association 83 (3): 277-295. https://doi.org/10.1080/01944363.2017.1322914.

Horst, M., E. Ringstrom, S. Tyman, M. Ward, V. Werner, and B. Born. 2011. Toward a more expansive understanding of food hubs. Journal of Agriculture, Food Systems, and Community Development 2 (1): 209-225. https://doi.org/10.5304/jafsc d.2011.021.017.

Ilieva, R.T. 2017. Urban food systems strategies: A promising tool for implementing the SDGs in practice. Sustainability 9: 1707. https ://doi.org/10.3390/su9101707.

Kerssen, T.M., and Z.W. Brent. 2017. Grounding the U.S. food movement: Bringing land into food justice. In The new food activism: Opposition, cooperation, and collective action, ed. A. Alkon and J. Guthman, 284-315. California: University of California Press.

Kirwan, J., and D. Maye. 2013. Food security framings within the UK and the integration of local. Journal of Rural Studies 29: 91-100. https://doi.org/10.1016/j.jrurstud.2012.03.002.

Kneafsey, M., L. Owen, E. Bos, K. Broughton, and M. Lennartsson. 2017. Capacity building for food justice in England: The contribution of charity-led community food initiatives. Local Environment 22 (5): 621-634. https://doi.org/10.1080/13549 839.2016.1245717.

Koc, M., R. Macrae, E. Desjardins, and W. Roberts. 2008. Getting civil about food: The interactions between civil society and the state to advance sustainable food systems in Canada. Journal of Hunger and Environmental Nutrition 3 (2-3): 122-144. https:// doi.org/10.1080/19320240802243175.

Lang, T., and D. Barling. 2012. Food security and food sustainability: Reformulating the debate. Geographical Journal 178 (4): 313-326. https://doi.org/10.1111/j.1475-4959.2012.00480.x.

Levkoe, C.Z. 2006. Learning democracy through food justice movements. Agriculture and Human Values 23 (1): 89-98. https://doi. org/10.1007/s10460-005-5871-5.

Loo, C. 2014. Towards a more participative definition of food justice. Journal of Agricultural and Environmental Ethics 27: 787-809. https://doi.org/10.1007/s10806-014-9490-2.

Manganelli, A., and F. Moulaert. 2019. Scaling out access to land for urban agriculture. Governance hybridities in the Brussels-Capital Region. Land Use Policy 82: 391-400. https://doi.org/10.1016/j. landusepol.2018.12.015.

Manganelli, A., P. van den Broeck, and F. Moulaert. 2019. Sociopolitical dynamics of alternative food networks: A hybrid governance approach. Territory, Politics, Governance 8 (3): 299-318. https://doi.org/10.1080/21622671.2019.1581081.

Mansfield, B., and W. Mendes. 2013. Municipal food strategies and integrated approaches to urban agriculture: Exploring three cases from the global north. International Planning Studies 18 (1): 37-60. https://doi.org/10.1080/13563475.2013.750942. 
Martin, K.S., B.L. Rogers, J.T. Cook, and H.M. Joseph. 2004. Social capital is associated with decreased risk of hunger. Social Science and Medicine 58 (12): 2645-2654. https://doi.org/10.1016/j. socscimed.2003.09.026.

Matacena, R. 2016. Linking alternative food networks and urban food policy: A step forward in the transition towards a sustainable and equitable food system? International Review of Social Research 6 (1): 49-58. https://doi.org/10.1515/irsr-2016-0007.

Maughan, C., C. Anderson, and M. Kneafsey. 2020. A five-point framework for reading for social justice: A case study of food policy discourse in the context of Brexit Britain. Journal of Agriculture, Food Systems, and Community Development 9 (3): 281-300. https://doi.org/10.5304/jafscd.2020.093.024.

Maye, D. 2019. 'Smart food city': Conceptual relations between smart city planning, urban food systems and innovation theory. City, Culture and Society 16: 18-24. https://doi.org/10.1016/j. ccs.2017.12.001.

Meek, D., and R. Tarlau. 2016. Critical food systems education (CFSE): Educating for food sovereignty. Agroecology and Sustainable Food Systems 40 (3): 237-260. https://doi.org/10.1080/21683 565.2015.1130764

Meerow, S., P. Pajouhesh, and T.R. Miller. 2019. Social equity in urban resilience planning. Local Environment 24 (9): 793-808. https:// doi.org/10.1080/13549839.2019.1645103.

Mendes, W. 2008. Implementing social and environmental policies in cities: The case of food policy in Vancouver, Canada. International Journal of Urban and Regional Research 32 (4): 942-967. https://doi.org/10.1111/j.1468-2427.2008.00814.x.

Moragues-Faus, A. 2017. Problematising justice definitions in public food security debates: Towards global and participative food justices. Geoforum 84: 95-106. https://doi.org/10.1016/j.geofo rum.2017.06.007.

Moragues-Faus, A., and B. Carroll. 2018. Reshaping urban political ecologies: An analysis of policy trajectories to deliver food security. Food Security 10: 1337-1351. https://doi.org/10.1007/s1257 1-018-0855-7.

Moragues-Faus, A., and K. Morgan. 2015. Reframing the foodscape: The emergent world of urban food policy. Environment and Planning A 47 (7): 1558-1573. https://doi.org/10.1177/0308518X15 595754.

Morgan, K. 2015. Nourishing the city: The rise of the urban food question in the Global North. Urban Studies 52 (8): 1379-1394. https ://doi.org/10.1177/0042098014534902.

Morrow, O. 2019. Community self-organizing and the urban food commons in Berlin and New York. Sustainability 11: 3641. https:// doi.org/10.3390/su11133641.

Navin, M.C., and J.M. Dieterle. 2018. Cooptation or solidarity: Food sovereignty in the developed world. Agriculture and Human Values 35 (2): 319-329. https://doi.org/10.1007/s10460-017-9823-7.

Neuner, K., S. Kelly, and S. Raja. 2011. Planning to eat: Innovative local government plans and policies to build healthy food systems in the United States. https://ubwp.buffalo.edu/foodlab/wpcontent/uploads/sites/68/2017/06/planningtoeat5.pdf.

Noll, S., and E.G. Murdock. 2019. Whose justice is it anyway? Mitigating the tensions between food security and food sovereignty. Journal of Agricultural and Environmental Ethics 33: 1-14. https ://doi.org/10.1007/s10806-019-09809-9.

Olsson, E.G.A., E. Kerselaers, L.S. Kristensen, J. Primdahl, E. Rogge, and A. Wästfelt. 2016. Peri-urban food production and its relation to urban resilience. Sustainability 8: 1340. https://doi. org/10.3390/su8121340.

Olsson, E.G.A. 2018. Urban food systems as vehicles for sustainability transitions. Bulletin of Geography 40 (40): 133-144. https://doi. org/10.2478/bog-2018-0019.

Passidomo, C. 2014. Whose right to (farm) the city? Race and food justice activism in post-Katrina New Orleans. Agriculture and
Human Values 31 (3): 385-396. https://doi.org/10.1007/s1046 0-014-9490-x.

Pothukuchi, K. 2009. Community and regional food planning: Building institutional support in the United States. International Planning Studies 14 (4): 349-367. https://doi.org/10.1080/13563 471003642902.

Pothukuchi, K., and J.L. Kaufman. 1999. Placing the food system on the urban agenda: The role of municipal institutions in food systems planning. Agriculture and Human Values 16 (2): 213-224. https://doi.org/10.1023/A:1007558805953.

Pothukuchi, K., and J.L. Kaufman. 2000. The food system: A stranger to the planning field. Journal of the American Planning Association 66 (2): 113-124. https://doi.org/10.1080/0194436000 8976093.

Prost, S. 2019. Food democracy for all? Developing a food hub in the context of socio-economic deprivation. Politics and Governance 7 (4): 142-153. https://doi.org/10.17645/pag.v7i4.2057.

Prové, C., M.P.M.M. de Krom, and J. Dessein. 2019. Politics of scale in urban agriculture governance: A transatlantic comparison of food policy councils. Journal of Rural Studies 68: 171-181. https ://doi.org/10.1016/j.jrurstud.2019.01.018.

Purifoy, D.M. 2014. Food policy councils: Integrating food justice and environmental justice. Duke Environmental Law \& Policy Forum 24 (375): 243-258. https://doi.org/10.3366/ajicl.2011.0005.

Renting, H., and J.S.C. Wiskerke. 2010. New emerging roles for public institutions and civil society in the promotion of sustainable local agro-food systems. 9th European IFSA Symposium, 4-7 July 2010, Vienna (Austria), 1902-1912.

Santo, R., and A. Moragues-Faus. 2018. Towards a trans-local food governance: Exploring the transformative capacity of food policy assemblages in the US and UK. Geoforum 98: 75-87. https://doi. org/10.1016/j.geoforum.2018.10.002.

Saulters, M.M., M.K. Hendrickson, and F. Chaddad. 2018. Fairness in alternative food networks: An exploration with midwestern social entrepreneurs. Agriculture and Human Values 35 (3): 611-621. https://doi.org/10.1007/s10460-018-9852-x.

Schiavoni, C.M. 2017. The contested terrain of food sovereignty construction: Toward a historical, relational and interactive approach. Journal of Peasant Studies 44 (1): 1-32. https://doi. org/10.1080/03066150.2016.1234455.

Schiff, R. 2008. The role of food policy councils in developing sustainable food systems. Journal of Hunger and Environmental Nutrition 3 (2-3): 206-228. https://doi.org/10.1080/1932024080 2244017.

Sherriff, G. 2009. Towards healthy local food: Issues in achieving Just Sustainability. Local Environment 14 (1): 73-92. https://doi. org/10.1080/13549830802522566.

Sibbing, L.V., J.J.L. Candel, and C.J.A.M. Termeer. 2019. A comparative assessment of local municipal food policy integration in the Netherlands. International Planning Studies. https://doi. org/10.1080/13563475.2019.1674642.

Silver, M., A. Bediako, T. Capers, A. Kirac, and N. Freudenberg. 2017. Creating integrated strategies for increasing access to healthy affordable food in urban communities: A case study of intersecting food initiatives. Journal of Urban Health 94 (4): 482-493. https://doi.org/10.1007/s11524-017-0178-6.

Slocum, R., and K.V. Cadieux. 2015. Notes on the practice of food justice in the U.S.: Understanding and confronting trauma and inequity. Journal of Political Ecology 22: 27-52. https://doi. org/10.2458/v22i1.21077

Smith, B.J. 2019. Food justice, intersectional agriculture, and the triple food movement. Agriculture and Human Values 36 (4): 825-835. https://doi.org/10.1007/s10460-019-09945-y.

Sonnino, R. 2009. Feeding the city: Towards a new research and planning agenda. International Planning Studies 14 (4): 425-435. https://doi.org/10.1080/13563471003642795. 
Sonnino, R. 2013. Local foodscapes: Place and power in the agrifood system. Acta Agriculturae Scandinavica Section B: Soil and Plant Science 63 (1): 2-7. https://doi.org/10.1080/09064 710.2013 .800130 .

Sonnino, R. 2016. The new geography of food security: Exploring the potential of urban food strategies. Geographical Journal 182 (2): 190-200. https://doi.org/10.1111/geoj.12129.

Sonnino, R. 2019. The cultural dynamics of urban food governance. City, Culture and Society 16: 12-17. https://doi.org/10.1016/j. ccs.2017.11.001.

Sonnino, R., and H. Coulson. 2020. Unpacking the new urban food agenda: The changing dynamics of global governance in the urban age. Urban Studies. https://doi.org/10.1177/0042098020 942036.

Sonnino, R., T.K. Marsden, and A. Moragues-Faus. 2016. Relationalities and convergences in food security narratives: Towards a place-based approach. Transactions of the Institute of British Geographers 41: 477-489. https://doi.org/10.1111/tran.12137.

Sonnino, R., C.L.S. Tegoni, and A. De Cunto. 2019. The challenge of systemic food change: Insights from cities. Cities 85: 110-116. https://doi.org/10.1016/j.cities.2018.08.008.

Šūmane, S., I. Kunda, K. Knickel, A. Strauss, T. Tisenkopfs, I. des Ios Rios, M. Rivera, T. Chebach, and A. Ashkenazy. 2018. Local and farmers' knowledge matters! How integrating informal and formal knowledge enhances sustainable and resilient agriculture. Journal of Rural Studies 59: 232-241. https://doi.org/10.1016/j. jrurstud.2017.01.020.

Swinburn, B., V. Kraak, H. Rutter, S. Vandevijvere, T. Lobstein, G. Sacks, F. Gomes, T. Marsh, and R. Magnusson. 2015. Strengthening of accountability systems to create healthy food environments and reduce global obesity. The Lancet 385 (9986): 25342545. https://doi.org/10.1016/S0140-6736(14)61747-5.

Tornaghi, C. 2014. Critical geography of urban agriculture. Progress in Human Geography 38 (4): 551-567. https://doi. org/10.1177/0309132513512542.

Tornaghi, C. 2017. Urban agriculture in the food-disabling city: (Re) defining urban food justice, reimagining a politics of empowerment. Antipode 49 (3): 781-801. https://doi.org/10.1111/ anti.12291.

Trienekens, J.H., P.M. Wognum, A.J.M. Beulens, and J.G.A.J. Van Der Vorst. 2012. Transparency in complex dynamic food supply chains. Advanced Engineering Informatics 26 (1): 55-65. https ://doi.org/10.1016/j.aei.2011.07.007.

Trivette, S.A. 2017. Invoices on scraps of paper: Trust and reciprocity in local food systems. Agriculture and Human Values 34 (3): 529-542. https://doi.org/10.1007/s10460-016-9738-8.

Vieira, L.C., S. Serrao-Neumann, M. Howes, and B. Mackey. 2018. Unpacking components of sustainable and resilient urban food systems. Journal of Cleaner Production 200: 318-330. https:// doi.org/10.1016/j.jclepro.2018.07.283.

Vitiello, D., and C. Brinkley. 2014. The hidden history of food system planning. Journal of Planning History 13 (2): 91-112. https:// doi.org/10.1177/1538513213507541.

Wald, N., and D.P. Hill. 2016. 'Rescaling' alternative food systems: From food security to food sovereignty. Agriculture and Human Values 33 (1): 203-213. https://doi.org/10.1007/s1046 0-015-9623-x.

Walker, R.E., C.R. Keane, and J.G. Burke. 2010. Disparities and access to healthy food in the United States: A review of food deserts literature. Health and Place 16 (5): 876-884. https://doi. org/10.1016/j.healthplace.2010.04.013.

Walsh-Dilley, M., W. Wolford, and J. McCarthy. 2016. Rights for resilience: Food sovereignty, power, and resilience in development practice. Ecology and Society 21 (1): 11. https://doi.org/10.5751/ ES-07981-210111.
Wekerle, G.R. 2004. Food justice movements: Policy, planning, and networks. Journal of Planning Education and Research 23 (4): 378-386. https://doi.org/10.1177/0739456X04264886.

West, P. 2010. Making the market: specialty coffee, generational pitches, and Papua New Guinea. Antipode 42 (3): 690-718. https ://doi.org/10.1111/j.1467-8330.2010.00769.x.

Weymes, M., and A.R. Davies. 2019. [Re]valuing surplus: Transitions, technologies and tensions in redistributing prepared food in San Francisco. Geoforum 99: 160-169. https://doi.org/10.1016/j. geoforum.2018.11.005.

Wilkins, J.L. 2005. Eating right here: Moving from consumer to food citizen. Agriculture and Human Values 22 (3): 269-273. https:// doi.org/10.1007/s10460-005-6042-4.

Wiskerke, J.S.C. 2009. On places lost and places regained: Reflections on the alternative food geography and sustainable regional development. International Planning Studies 14 (4): 367-387. https://doi.org/10.1080/13563471003642803.

Wittman, H. 2011. Food sovereignty: A new rights framework for food and nature? Environment and Society 2: 87-105. https:// doi.org/10.3167/ares.2011.020106.

Publisher's Note Springer Nature remains neutral with regard to jurisdictional claims in published maps and institutional affiliations.

Sara Smaal is a PhD researcher at the Flanders Research Institute for Agriculture, Fisheries and Food (ILVO) and Ghent University in Belgium, and an ESR in the MSCA ITN RECOMS. She developed an academic background in human geography and planning at Utrecht University (BSc) and the University of Groningen (MSc) in the Netherlands, and is passionate about transdisciplinary and participatory research. Her current $\mathrm{PhD}$ study focusses on justice-oriented narratives in the development and implementation trajectories of European urban food policies.

Joost Dessein is associate professor (tenured) at the Department of Agricultural Economics at Ghent University. He holds an MSc in Agricultural Engineering and an MSc and PhD in Social and Cultural Anthropology, all of which obtained at the Catholic University of Louvain. His research expertise lies in the field of Sociology of Agriculture and Food and Rural Development. He is president of the European Society for Rural Sociology.

Barend Wind is assistant professor Socio-Spatial Planning at the Department of Spatial Planning and Environment at the University of Groningen. As a researcher, he mainly reflects on housing provision and allocation from a social- and spatial justice point of view. He studies emerging forms of inequality and institutional arrangements that reinforce or temper social and spatial forms of (housing-related) inequality. Particular attention is paid to the impact of privatization and commodification processes on the costs and benefits of urban life for several social groups.

Elke Rogge is scientific director at the Social Sciences Unit of ILVO. She graduated as a geographer at Ghent University in 2001. After making a $\mathrm{PhD}$ on landscape perception and participation, she started working at the Social Sciences Unit of ILVO in 2007. Her research mainly focusses on territorial governance and participation within spatial planning processes in rural areas. The last couple of years she coordinated several research projects on the role of agriculture in peri-urban areas and the governance of (local) food networks. 